\title{
The hexane fraction of Ardisia crispa Thunb. A. DC. roots inhibits inflammation-induced angiogenesis
}

\author{
Dayang Erna Zulaikha Awang Hamsin ${ }^{1,3+}$, Roslida Abdul Hamid ${ }^{1 *}$, Latifah Saiful Yazan', Che Norma Mat Taib ${ }^{2 \dagger}$ \\ and Yeong Looi Ting ${ }^{1+}$
}

\begin{abstract}
Background: Ardisia crispa (Myrsinaceae) is used in traditional Malay medicine to treat various ailments associated with inflammation, including rheumatism. The plant's hexane fraction was previously shown to inhibit several diseases associated with inflammation. As there is a strong correlation between inflammation and angiogenesis, we conducted the present study to investigate the anti-angiogenic effects of the plant's roots in animal models of inflammation-induced angiogenesis.

Methods: We first performed phytochemical screening and high-performance liquid chromatography (HPLC) fingerprinting of the hexane fraction of Ardisia crispa roots ethanolic extract (ACRH) and its quinone-rich fraction (QRF). The anti-inflammatory properties of ACRH and QRF were tested using the Miles vascular permeability assay and the murine air pouch granuloma model following oral administration at various doses.

Results: Preliminary phytochemical screening of ACRH revealed the presence of flavonoids, triterpenes, and tannins. The QRF was separated from ACRH $(38.38 \% \mathrm{w} / \mathrm{w})$ by column chromatography, and was isolated to yield a benzoquinonoid compound. The ACRH and QRF were quantified by HPLC. The LD 50 value of ACRH was $617.02 \mathrm{mg} / \mathrm{kg}$. In the Miles vascular permeability assay, the lowest dose of ACRH $(10 \mathrm{mg} / \mathrm{kg})$ and all doses of QRF significantly reduced vascular endothelial growth factor (VEGF)-induced hyperpermeability, when compared with the vehicle control. In the murine air pouch granuloma model, ACRH and QRF both displayed significant and dose-dependent anti-inflammatory effects, without granuloma weight. ACRH and QRF significantly reduced the vascular index, but not granuloma tissue weight.
\end{abstract}

Conclusions: In conclusion, both ACRH and QRF showed potential anti-inflammatory properties in a model of inflammation-induced angiogenesis model, demonstrating their potential anti-angiogenic properties.

Keywords: Ardisia crispa, Miles vascular permeability assay, Murine air pouch granuloma, Angiogenesis

\section{Background}

Angiogenesis is the process of blood vessel formation. It is important in normal physiology and is involved in the progression of chronic diseases, particularly cancer, arthritis and cardiovascular diseases [1-7]. The advantage of targeting angiogenesis to control pathological disorders, particularly cancer, is that anti-angiogenic agents specifically target newly formed blood vessels without damaging existing blood vessels [1]. The important role of angiogenesis in the pathogenesis of chronic inflammatory diseases has

\footnotetext{
* Correspondence: roslida@medic.upm.edu.my

${ }^{\dagger}$ Equal contributors

'Department of Biomedical Science, Faculty of Medicine and Health Sciences, Universiti Putra Malaysia, Serdang, Selangor 43400, Malaysia Full list of author information is available at the end of the article
}

led to the implementation of anti-angiogenic strategies for treating these diseases [8].

Drugs are increasingly being developed from natural products, offering a very promising approach to identify novel anti-angiogenic and anti-cancer agents [9]. A considerable number of bioactive compounds derived from functional and medicinal foods have been identified as potential anti-angiogenic agents based on the results of experimental and clinical studies. Compounds such as curcumin in turmeric [10], naringenin in citrus [11], humulone in beer hop [12], betulinic acid in almond hull [13], capsaicin in pepper [14] and resveratrol in grapes $[15,16]$ were reported to inhibit angiogenesis by targeting the cyclooxygenase-2 (COX-2) and 5-lipoxygenase

\section{Biomed Central}

(c) 2013 Awang Hamsin et al.; licensee BioMed Central Ltd. This is an Open Access article distributed under the terms of the Creative Commons Attribution License (http://creativecommons.org/licenses/by/2.0), which permits unrestricted use, distribution, and reproduction in any medium, provided the original work is properly cited. 
(5-LOX) pathways. Inhibition of the COX-2 pathway, for example, was shown to reduce prostaglandin $\mathrm{E}_{2}\left(\mathrm{PGE}_{2}\right)$ production [17], which may suppress vascular endothelial growth factor (VEGF) expression [18], a key mediator of in vitro angiogenesis [19].

Ardisia crispa Thunb A.DC is an evergreen shrub belonging to Myrsinaceae family, and is widely distributed and indigenous throughout Asia. In Malaysia, Ardisia crispa can be found in the undergrowth of jungle peripheries, in dappled shade, and in shady regions [20]. In Peninsular Malaysia, it is locally known as "Mata Ayam" or "Mata Itik". The roots and leaves of the plant have been used by local villagers to treat various ailments as part of local traditional medicine. The roots were used as an ingredient to treat postnatal syndromes, while its boiled concoction was used to treating throat and chest discomfort, and rheumatism. The root's juice was also reported to be useful for treating earache, cough, fever, and diarrhoea [21].

Phytochemical studies reported that several pharmacologically active compounds, including triterpenoid saponins [22], n-peptide [23], and benzoquinone [24] were isolated from Ardisia crispa. Meanwhile, its hexane fraction was reported to have anti-ulcerogenic [25], as well as having anti-inflammatory and anti-hyperalgesic properties in vivo [26]. Additionally, a benzoquinonoid compound, 2-methoxy-6-undercyl-1,4-benzoquinone (Figure 1), was isolated from the hexane fraction of Ardisia crispa roots and exhibited anti-inflammatory properties in vivo [27].
Angiogenesis plays an essential role in the initiation and progression of chronic inflammatory disorders [28]. It was proposed that angiogenesis is closely linked to inflammation in that they share similar activating pathways, including COX-2 [29,30]. Pro-inflammatory mediators, such as $\mathrm{PGE}_{2}$, were shown to induce angiogenesis in vivo [31,32], partly by increasing the expression of VEGF, a potent angiogenic factor [33,34]. Therefore, while Ardisia crispa roots were previously demonstrated to possess antiinflammatory properties, it seems feasible that Ardisia crispa roots might also have anti-angiogenic properties, based on the significant correlation between inflammation and angiogenesis shown in previous reports [28,35]. Therefore, we conducted this study to explore the potential anti-angiogenic properties of Ardisia crispa roots. It is hoped that the findings from this study would provide a scientific basis to carry out further studies on the antiangiogenic properties of Ardisia crispa roots.

\section{Methods}

\section{Chemicals and drugs}

Silica gel 60 (70-230 mesh), thin-layer chromatography (TLC) silica gel $\left(60 \mathrm{~F}_{254} 0.25 \mathrm{~mm}\right)$, methanol and chloroform were purchased from Merck (Munchen, Germany). Trifluoroacetic acid (TFA) was purchased from Alfa Aesar (Wardhill, MA, USA). Phosphate-buffered saline (PBS), VEGF 165, carboxymethylcellulose (CMC), Evans Blue dye, formamide, carmine red, papain $12 \mathrm{U} / \mathrm{mL}$, and

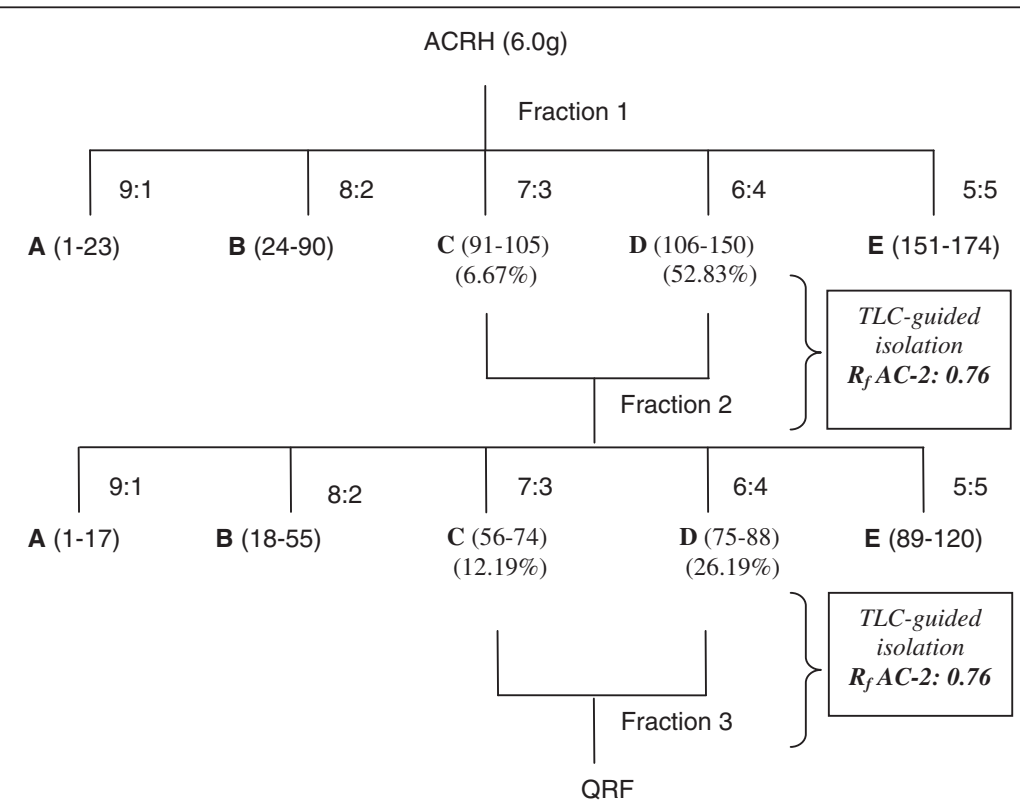

(38.38\%)

Figure 1 Chromatographic separation and fractionation of Ardisia crispa roots. Column chromatographic separation was repeated three times to collect QRF (38.38\% w/W). A-E represent the five major fractions obtained using the hexane:ethyl acetate gradients. Fraction 1: AC-2 Rf 0.76 in fractions $\mathbf{C}$ and $\mathbf{D}$ (vials $91-150$ ). The mixture of fractions $\mathbf{C}$ and $\mathbf{D}$ obtained in fraction 1 was separated to yield fraction 2. Fraction 2: AC-2 Rf 0.76 in fractions $\mathbf{C}$ and $\mathbf{D}$ (vials 56-88). The mixture of $\mathbf{C}$ and $\mathbf{D}$ from fraction 2 was separated again to yield QRF. 
EDTA, $N$-acetylcysteine and indomethacin (purity > 99\%) were purchased from Sigma (St. Louis, MO, USA). All other reagents were of analytical grade and were purchased from commercial sources.

\section{Plant material}

Ardisia crispa roots (ACR) were collected in Machang (Kelantan, Malaysia) in April 2010, and were identified by Dr. Roslida Abdul Hamid (Universiti Putra Malaysia). A voucher specimen (20841) was deposited at the Herbarium of Universiti Kebangsaan Malaysia. ACR was dried in an oven for 5 days at $60^{\circ} \mathrm{C}$ (Memmert, Germany). The roots were then pulverised into coarse powder by using a mill grinder (Retsch, Germany). Compounds were extracted from ACR using the Soxhlet method. Briefly, $600 \mathrm{~g}$ of powdered ACR was extracted using $80 \%$ ethanol at a temperature of $80-90^{\circ} \mathrm{C}$ under reflux $(3 \times 2000 \mathrm{~mL}, 72 \mathrm{~h}$ each), then filtered and concentrated using rotary vacuum evaporator to yield Ardisia crispa ethanolic extract (ACRE). The ACRE was then fractionated using absolute $n$-hexane $(3 \times 1000 \mathrm{~mL}$, $72 \mathrm{~h}$ each). The filtrate was concentrated under reduced pressure, yielding the Ardisia crispa root hexane fraction (ACRH).

\section{Phytochemical analysis}

Preliminary phytochemical analysis of ACRH was carried out to detect the presence of alkaloids, saponin, flavonoids, tannins, polyphenolic compounds, triterpenes and steroids, using a previously described method [36].

\section{Separation of the quinone-rich fraction (QRF)}

Approximately $6 \mathrm{~g}$ of ACRH were loaded through a column $(65 \mathrm{~cm} \times 2 \mathrm{~cm})$ packed with $200 \mathrm{~g}$ of 70-230 mesh silica gel (Merck). The sample was eluted with a mobile phase consisting of hexane:ethyl acetate (9:1-5:5 $[\mathrm{v} / \mathrm{v}], 500 \mathrm{~mL}$ ) at a constant flow rate. The eluents were collected in 20-mL fractions (Figure 1). TLC was used to qualitatively identify the presence of compounds by comparing the retention factor $\left(R_{f}\right)$ of individual compounds in each fraction relative to those of reference compounds. Chloroform was used as the developing solvent. Compounds were detected under an UV lamp at a wavelength of $254 / 356 \mathrm{~nm}$ (Mineralight ${ }^{\circledR}$ ) and by heating the TLC plates with $10 \%$ sulphuric acid $\left(\mathrm{H}_{2} \mathrm{SO}_{4}\right)$. Vials containing compounds with similar $\mathrm{R}_{\mathrm{f}}$ values under $\mathrm{H}_{2} \mathrm{SO}_{4}$ were combined together to obtain the QRF. The $\mathrm{R}_{\mathrm{f}}$ of this fraction was compared with that of the pure compound, AC2 , as obtained in a previous study [27]. AC-2, isolated from the Ardisia crispa roots, was provided by Dr Roslida Abdul Hamid. The compound was previously characterised by gas chromatography/mass spectrometry and nuclear magnetic resonance, and was identified as 2-methoxy-6-undecyl-1,4-benzoquinone (Figure 2) [27].

\section{HPLC analysis of QRF}

We performed HPLC using the method reported by Shelar et al. [37], with slight modifications. The HPLC system consisted of an Agilent 1290 series Ultra Performance Liquid Chromatography (UPLC) equipped with an auto sampler, a diode array detector (DAD) and a reverse-phase analytical column (HyperClone 3u ODS C18, $3 \mu \mathrm{m}, 4.0 \times$ $125 \mathrm{~mm}$; Phenomenex, USA). The mobile phase consisted of methanol (A) and 0.1\% TFA (B) $(88: 12[\mathrm{v} / \mathrm{v}])$, and was degassed before use. The flow-rate was kept at $1.0 \mathrm{~mL} /$ min. The temperature of column was held at $29.99 \pm 1^{\circ} \mathrm{C}$. The injection volume was $20 \mu \mathrm{L}$. Detection was carried out at $288 \mathrm{~nm}$.

\section{Experimental animals}

Male ICR mice (25-30 g) at 6-8 weeks of age were used in this study. Six mice were housed per cage under standard laboratory conditions (temperature $25 \pm 2^{\circ} \mathrm{C}$ and 12-h light/dark cycle). The animals had free access to water and food pellets ad libitum. Mice were acclimatised for 1 week before experiments. Ethical clearance was obtained from the Animal Care and Use Committee (ACUC), Faculty of Medicine and Health Sciences, Universiti Putra Malaysia, Malaysia (Reference number: UPM/FPSK/PADS/UUH/F05).

\section{Acute oral toxicity}

ICR mice were allotted into groups of 10 animals each and were divided into seven different groups to assess the acute toxicity of ACRH, as previously described [38] ACRH was administered orally at single doses of 300 , $400,500,800,1200,1600$ and $1800 \mathrm{mg} / \mathrm{kg}$. The time of administration was recorded and the mice were carefully examined for any clinical symptoms and abnormal behaviour. The number of deaths and toxicity signs in each group were recorded for $48 \mathrm{~h}$. The proportion of mice that died in each group was calculated and plotted against the dose to determine the median lethal dose $\left(\mathrm{LD}_{50}\right)$.

\section{Miles vascular permeability test}

The vascular permeability assay was carried out according to the method of Pakhneshan et al. [39] with some modifications. Eight groups of six randomly selected

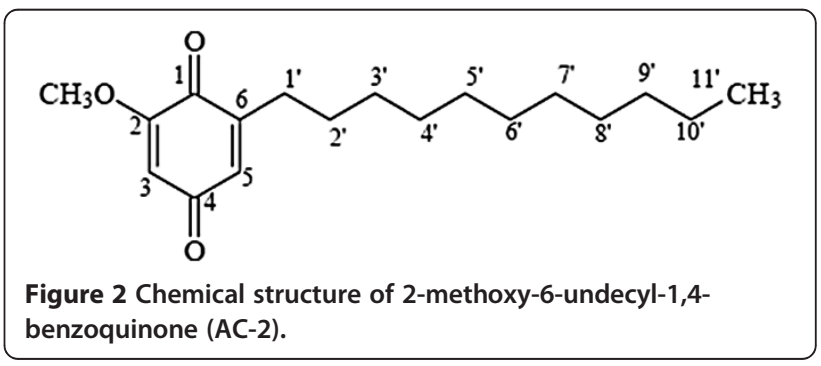


mice per group were orally administered with a vehicle control (5\% CMC), a positive control $(10 \mathrm{mg} / \mathrm{kg}$ indomethacin), or with 10,30 , or $100 \mathrm{mg} / \mathrm{kg}$ of $\mathrm{ACRH}$ or QRF every day for 5 days. On day 6, the mice were first anesthetised with an intraperitoneal injection of Avertin mixture $(10 \mathrm{~mL} / \mathrm{kg})$. Next, $100 \mu \mathrm{L}$ of Evans blue $(1 \%$ in $0.9 \%$ saline) was injected intravenously via a lateral tail vein. After $10 \mathrm{~min}, 50 \mu \mathrm{L}$ of VEGF $(1 \mathrm{ng} / \mu \mathrm{L})$ was injected intradermally into the dorsal area. After $20 \mathrm{~min}$, the mice were euthanised and a skin sample $\left(1 \mathrm{~cm}^{2}\right)$ was harvested, weighed, and incubated at $56^{\circ} \mathrm{C}$ for $24 \mathrm{~h}$. The skin samples were then extracted in $1 \mathrm{~mL}$ formamide for 5 days at room temperature. The optical density of the formamide extract was determined at $620 \mathrm{~nm}$ (Shimadzu, Japan).

\section{Murine air pouch granuloma}

This method was carried out as previous described with some modifications [40]. A total of 48 mice was randomly divided into eight groups ( $n=6 \mathrm{mice} /$ group) and treated with the vehicle control $(0.5 \% \mathrm{CMC}), 10 \mathrm{mg} / \mathrm{kg}$ indomethacin, or 10,30 , or $100 \mathrm{mg} / \mathrm{kg}$ ACRH or QRF. Air pouches were induced on day 1 by injecting $5 \mathrm{~mL}$ of filtered air $(0.2 \mu \mathrm{m}$ mesh) into the dorsal region of the mice. On days 3 and 5, approximately $3 \mathrm{~mL}$ of filtered air was injected again to maintain the air pouch. On the following day, $0.2 \mathrm{~mL}$ of $0.1 \%$ croton oil in Freund's Complete Adjuvant $(\mathrm{FA} ; \mathrm{v} / \mathrm{v})$ was injected into the air pouch cavity. After Freund's Complete Adjuvant (FCA) injection, the specified treatments were administered orally for 1 week to conscious mice. After 1 week of treatment, vascular casts were prepared by intravenously injecting $1 \mathrm{~mL}$ of $10 \%$ carmine red in $5 \%$ gelatine solution into the tail vein. The granulomatous pouch lining was treated as previously described [41]. The animals were chilled at $2-4^{\circ} \mathrm{C}$ for $4 \mathrm{~h}$ before removing the granuloma tissues. The granuloma tissues were dried at $56^{\circ} \mathrm{C}$ for $48 \mathrm{~h}$ and weighed. The dried tissues were cut and digested in $2 \mathrm{~mL}$ of digestive juice $(12,000$ $\mathrm{U} / \mathrm{L}$ papain, $1 \mathrm{mmol} / \mathrm{L}$ EDTA, and $0.33 \mathrm{~g} / \mathrm{L} N$-acetylcysteine in PBS, $\mathrm{pH} 7.0$ ) for $48 \mathrm{~h}$ at $56^{\circ} \mathrm{C}$. Subsequently, $0.2 \mathrm{~mL} 5 \mathrm{~mol} / \mathrm{l} \mathrm{NaOH}$ was added to neutralise carminic acid. The solution was centrifuged at $2000 \times g$ for $5 \mathrm{~min}$ utes. The supernatant was then filtered using a $0.2 \mu \mathrm{m}$ syringe filter and the optical density of the filtrate was measured at $540 \mathrm{~nm}$. The vascular index, as an index of new formation of blood vessels in the granuloma tissue lining, was determined by dividing carmine dye content by dry granuloma tissue $(\mathrm{mg} / \mathrm{g})$ [41].

\section{Statistical analysis}

All data are expressed as means \pm standard error of the mean (SEM) ( $n=6$ mice/group). One-way analysis of variance followed by the least significance difference post hoc test was used for statistical analyses, and were performed using SPSS software (version 16).

\section{Results}

\section{Plant extraction}

Extraction of Ardisia crispa roots with aqueous 80\% ethanol yielded approximately $81.16 \mathrm{~g}(13.53 \% \mathrm{w} / \mathrm{w})$ of ACRE. Further fractionation with n-hexane yielded $21.01 \mathrm{~g}(25.87 \% \mathrm{w} / \mathrm{w})$ of ACRH. Preliminary phytochemical screening of ACRH indicated the presence of flavonoids, triterpenes and tannins. Further separation of ACRH yielded about $2.3 \mathrm{~g}(38.38 \% \mathrm{w} / \mathrm{w})$ of QRF.

\section{Chromatographic analysis of ACRH and QRF}

Eluents collected from the chromatography column loaded with $6 \mathrm{~g}$ of ACRH were run in a mobile phase, consisting of a gradient solvent of n-hexane/ethyl acetate at the ratio of 7:3-6:4, to harvest fraction 2 . Fraction 2 was further re-chromatographed at a similar ratio of n-hexane/ethyl acetate to yield fraction 3, which was labelled as QRF. Qualitative analysis of QRF, by TLC, revealed the presence of a compound with similar chemical characteristics to a benzoquinonoid compound (AC-2) along with a few other spots. The QRF had a similar $R_{\mathrm{f}}$ to $\mathrm{AC}-2\left(\mathrm{R}_{\mathrm{f}}=0.76\right)$, which was detected as a pink spot at $254 \mathrm{~nm}$, and turned black after being sprayed with $\mathrm{H}_{2} \mathrm{SO}_{4}$ and heated.

An HPLC-based method was successfully applied using a reverse-phase column with UV detection at $288 \mathrm{~nm}$ using HPLC-grade methanol as the mobile phase. This method resolved three major peaks for QRF (Figure 3a). The HPLC spectra for QRF showed major peaks at the retention times (in min) of 2.878, 3.903 and 4.348 at a wavelength of $288 \mathrm{~nm}$. The major peak at $\mathrm{R}_{\mathrm{t}}=2.878$ appeared to be AC-2 (2-methoxy-6-undecyl1,4-benzoquinone) when compared with the spectrum for the reference compound (Figure 3b).

\section{Oral acute toxicity}

$\mathrm{LD}_{50}$ was determined from the mortality curve and the $\mathrm{LD}_{50}$ of ACRH was found to be $617.02 \mathrm{mg} / \mathrm{kg}$.

\section{Miles vascular permeability assay}

In order to evaluate the anti-angiogenic potential of $\mathrm{ACRH}$ and QRF, we determined their inhibitory effects on vascular permeability. A standard curve of Evans blue dye concentration $(\mathrm{mg} / \mathrm{mL})$ versus absorbance (OD) was plotted (Figure 4). In the vehicle-treated group, the Evans blue dye concentration was $0.0597 \pm 0.005 \mathrm{mg} /$ $\mathrm{mL}$. Administration of $10 \mathrm{mg} / \mathrm{kg}$ ACRH significantly reduced VEGF-induced vascular permeability with an Evans blue dye concentration of $0.0367 \pm 0.008 \mathrm{mg} / \mathrm{mL}$ $(P<0.01)$, as compared with the vehicle control. However, ACRH at doses of 30 and $100 \mathrm{mg} / \mathrm{kg}$ did not have a significant inhibitory effect. QRF significantly reduced vascular permeability, as the Evans blue dye concentrations at doses of 10,30 and $100 \mathrm{mg} / \mathrm{kg}$ were $0.0305 \pm$ 


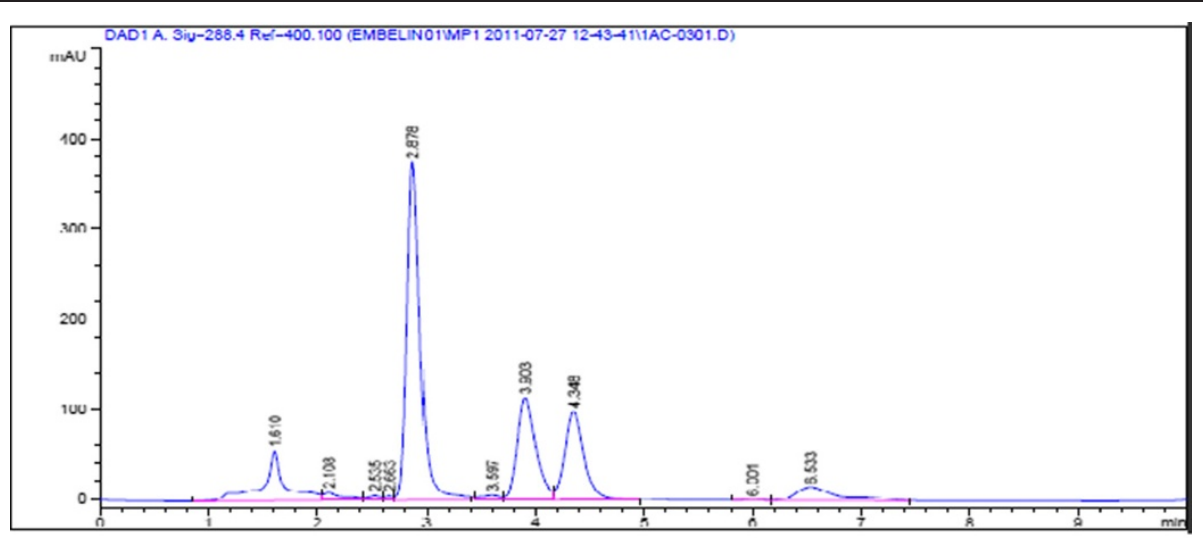

(a)

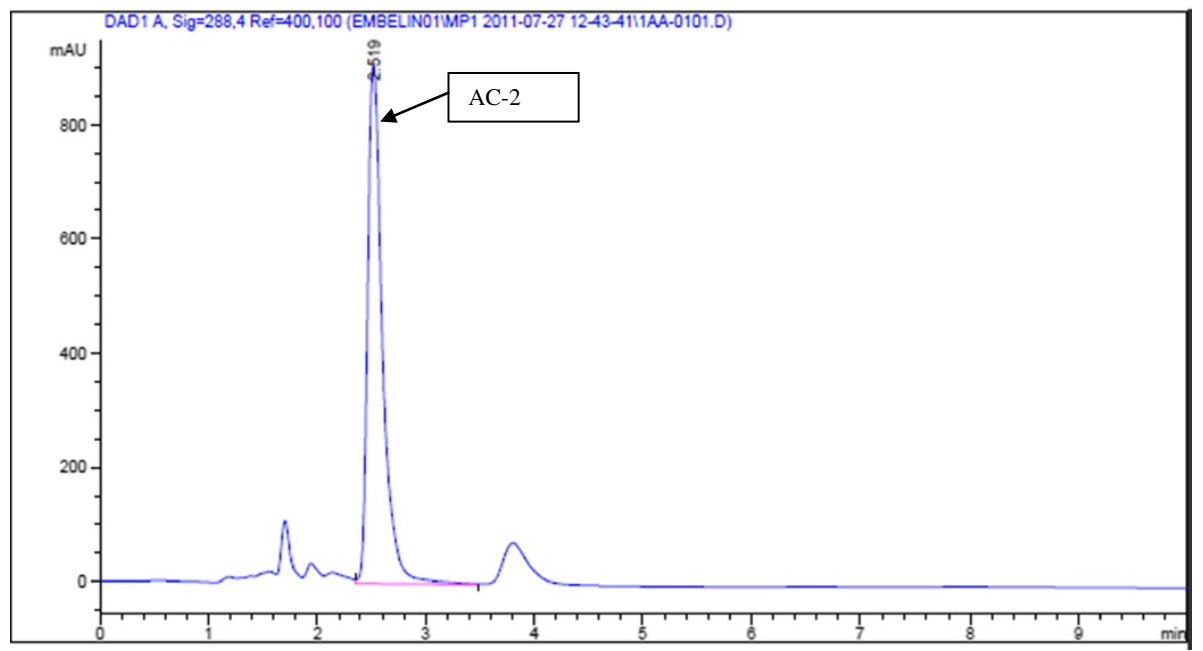

(b)

Figure 3 High performance liquid chromatography (HPLC) fingerprints of QRF (a) and AC-2 (b). $R_{t}$ for $A C_{2}=2.878$ min. HPLC fingerprint of another benzoquinonoid compound isolated from QRF in Ardisia crispa roots $\left(R_{t}=2.619 \mathrm{~min}\right)$.

$0.005 \mathrm{mg} / \mathrm{mL}(P<0.001), 0.0405 \pm 0.006(P<0.05)$ and $0.0373 \pm 0.005(P<0.01)$ respectively, when compared with the vehicle control (Table 1). The administration of $10 \mathrm{mg} / \mathrm{kg}$ indomethacin also significantly reduced the Evans blue dye concentration to $0.0340 \pm 0.005(P<0.01)$, which is as equipotent to ACRH and the lower dose of QRF (10 mg/kg). The extent of vascular permeability inhibition, as a percentage of that in the control group, was $38.53 \%, 48.91 \%$ and $43.05 \%$ for ACRH, QRF and indomethacin, respectively, at doses of $10 \mathrm{mg} / \mathrm{kg}$ (Table 1).

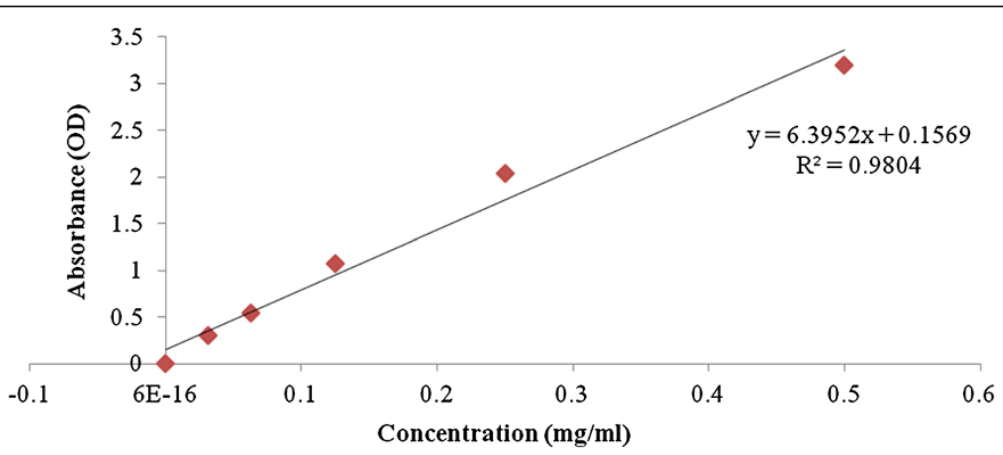

Figure 4 Standard curve for Evans Blue dye concentration $(\mathrm{mg} / \mathrm{mL})$ versus optical density. 


\begin{tabular}{|c|c|c|c|}
\hline Treatment group & $\begin{array}{l}\text { Dose } \\
(\mathrm{mg} / \mathrm{kg})\end{array}$ & $\begin{array}{l}\text { Vascular Index } \\
\text { (VI) }(\mathrm{mg} / \mathrm{g})\end{array}$ & Inhibition (\%) \\
\hline $\begin{array}{l}\text { Vehicle control } \\
\text { (CMC) } 5 \%\end{array}$ & - & $0.0597 \pm 0.005$ & - \\
\hline Indomethacin & 10 & $0.0340 \pm 0.005^{* *}$ & 43.05 \\
\hline \multirow[t]{3}{*}{$\mathrm{ACRH}$} & 10 & $0.0367 \pm 0.008^{* *}$ & 38.53 \\
\hline & 30 & $0.0495 \pm 0.005$ & 17.08 \\
\hline & 100 & $0.0438 \pm 0.007$ & 26.63 \\
\hline \multirow[t]{3}{*}{ QRF } & 10 & $0.0305 \pm 0.005^{* * *}$ & 48.91 \\
\hline & 30 & $0.0405 \pm 0.006^{*}$ & 32.19 \\
\hline & 100 & $0.0373 \pm 0.005^{* *}$ & 37.52 \\
\hline
\end{tabular}

Data are means \pm SEM ( $n=6$ mice/group). ${ }^{*} P<0.05,{ }^{* *} P<0.01$ and ${ }^{* * *} P<0.001$ versus vehicle control.

\section{Murine air pouch granuloma}

The inhibitory effects of ACRH and QRF on angiogenesis and inflammatory processes were evaluated by establishing adjuvant-induced air pouch granuloma in mice, and were measured in terms of the vascular index (VI) and granuloma tissue dry weight. In the vehicle control group, the VI was $1.599 \pm 0.091 \mathrm{mg} / \mathrm{g}$ tissue weight. Administration of 30 and $100 \mathrm{mg} / \mathrm{kg}$ ACRH significantly reduced VI compared with the vehicle control, with values of $1.064 \pm 0.126$ and $0.912 \pm 0.053 \mathrm{mg} / \mathrm{g}$ tissue weight, respectively, (both, $P<0.001)$. All three doses of QRF significantly reduced VI relative to the control group, with values of $0.956 \pm 0.054$, $0.586 \pm 0.108$ and $0.444 \pm 0.051 \mathrm{mg} / \mathrm{g}$ tissue weight at doses of 10, 30 and $100 \mathrm{mg} / \mathrm{kg}$, respectively (all, $P<0.001$ ). Meanwhile, $10 \mathrm{mg} / \mathrm{kg}$ indomethacin significantly reduced VI to $1.028 \pm 0.103 \mathrm{mg} / \mathrm{g}$ tissue weight $(P<0.001)$, and was equipotent to the lower dose of QRF. The inhibitory effects of ACRH and QRF on VI were dose-dependent (Table 2). The $\mathrm{ED}_{50}$ for $\mathrm{QRF}$ was $28.38 \mathrm{mg} / \mathrm{g}$ tissue weight.

Interestingly, we found a different pattern of results in terms of granulomatous tissue dry weight, although there was still evidence for dose-dependent effects of $\mathrm{ACRH}$ and QRF. The granulomatous dry tissue weight in the vehicle control group was $0.446 \pm 0.044 \mathrm{~g}$, and was significantly reduced in the $10 \mathrm{mg} / \mathrm{kg}$ indomethacin group to $0.307 \pm 0.011 \mathrm{~g}$. Of note, only ACRH at $100 \mathrm{mg} / \mathrm{kg}$ significantly reduced granulomatous tissue dry weight relative to the control group, with a weight of $0.303 \pm 0.024 \mathrm{~g}(P<0.05)$. The decrease in granulomatous try tissue weight was not significant at any dose of QRF relative to the vehicle control group (Table 3). Thus, these results suggested that anti-angiogenic activity of QRF, as evidenced by the decrease in VI, did not result in marked reductions in weight of the granulomatous tissue.

\section{Discussion}

Ardisia species are rich in polyphenols, triterpenoid saponins, isocoumarins, quinones and alkylphenols. Ardisia species and their constituents exhibit a wide range of biological activities, indicating that some of these plants could be exploited for the development of novel phytopharmaceuticals [42]. Ardisia japonica and Ardisia sieboldii, for example, were reported to inhibit 5-lipoxygenase [43,44], and therefore suppress inflammatory activities. Some Ardisia species were also reported to possess cytotoxic activities in vitro $[45,46]$. Because inhibition of angiogenesis has the potential to suppress tumour growth and metastases, its inhibition is one of the most promising strategies in the development of novel anti-cancer therapies, and in the treatment of other human diseases associated with angiogenesis. Thus far, however, no-one has reported on the anti-angiogenic properties of any Ardisia species, including Ardisia crispa.

Our preliminary phytochemical analysis of ACRH revealed that it contained significant amounts of triterpenes, flavonoids, and tannins. Although, the phytochemical screening did not reveal the presence of a benzoquinone, it was detected in the HPLC profiles of QRF when compared with the reference AC-2 compound, 2-methoxy-6-undecyl-1,4-benzoquinone. Benzoquinonoid isolated from Ardisia crispa was previously reported to possess anti-tumour and anti-metastatic properties in vitro [24].

The $\mathrm{LD}_{50}$ of $\mathrm{ACRH}$ was $617 \mathrm{mg} / \mathrm{kg}$ in the acute toxicity test. The doses of ACRH and QRF used in the experiments to determine their biological activities elicited no apparent behavioural side effects or signs of toxicity, such as convulsions. Nevertheless, a complete toxicity assessment of ACRH is needed to determine the margin of safety between the efficacy and toxicity of Ardisia crispa roots.

Several models are used to quantify angiogenesis and to evaluate the activities of candidate anti-angiogenic agents.

Table 2 Effects of ACRH and QRF on the vascular index (VI) of air pouch granuloma

\begin{tabular}{llll}
\hline Treatment group & $\begin{array}{l}\text { Dose } \\
(\mathbf{m g} / \mathbf{k g})\end{array}$ & $\begin{array}{l}\text { Vascular Index } \\
(\mathbf{V I}) \mathbf{( m g} / \mathbf{g})\end{array}$ & Inhibition (\%) \\
\hline Control (CMC) & $0.5 \%$ & $1.599 \pm 0.091$ & - \\
Indomethacin & 10 & $1.028 \pm 0.103^{*}$ & 35.71 \\
$\mathrm{ACRH}$ & 10 & $1.366 \pm 0.089$ & 14.57 \\
& 30 & $1.064 \pm 0.126^{*}$ & 33.45 \\
& 100 & $0.912 \pm 0.053^{*}$ & 42.64 \\
TQRF & 10 & $0.956 \pm 0.054^{*}$ & 40.21 \\
& 30 & $0.586 \pm 0.108^{*}$ & 63.39 \\
& 100 & $0.444 \pm 0.051^{*}$ & 72.23 \\
\hline
\end{tabular}

Data are means \pm SEM ( $n=6$ mice/group). VI was calculated as mg carmine dye content per gram tissue. ${ }^{*} P<0.001$ versus vehicle control. 


\begin{tabular}{|c|c|c|c|}
\hline Treatment group & $\begin{array}{l}\text { Dose } \\
(\mathrm{mg} / \mathrm{kg})\end{array}$ & $\begin{array}{l}\text { Granuloma tissue } \\
\text { dry weight (g) }\end{array}$ & Inhibition (\%) \\
\hline Control (CMC) & $0.5 \%$ & $0.446 \pm 0.044$ & - \\
\hline Indomethacin & 10 & $0.307 \pm 0.011^{*}$ & 31.17 \\
\hline \multirow[t]{3}{*}{$\mathrm{ACRH}$} & 10 & $0.511 \pm 0.048$ & - \\
\hline & 30 & $0.346 \pm 0.029$ & 22.42 \\
\hline & 100 & $0.303 \pm 0.024^{*}$ & 32.06 \\
\hline \multirow[t]{3}{*}{ TQRF } & 10 & $0.483 \pm 0.056$ & - \\
\hline & 30 & $0.473 \pm 0.040$ & - \\
\hline & 100 & $0.388 \pm 0.019$ & - \\
\hline
\end{tabular}

Data are means \pm SEM $(n=6) .{ }^{*} P<0.05$ versus vehicle control.

These include in vivo models such as chorioallantoic membrane [47], rabbit cornea [48] and rat air pouch [49]. In the Miles vascular permeability assay, indomethacin was used as a positive control because it is an established anti-angiogenic agent, based on data obtained in the cornea and tumour [50]. Additionally, indomethacin was reported to strongly suppress VEGF-induced permeability in mice [39].

VEGF is a key factor in angiogenesis and vascular permeability, being involved in many pathological processes. VEGF-induced permeability in this assay was quantified by prior intravenous injection of Evans blue dye into the mice. Evans blue dye binds to plasma proteins and is a marker for vascular hyperpermeability to macromolecules. Increased permeability is measured by spectrophotometric quantification of the blue dye [51]. In the Miles assay, both ACRH and QRF significantly reduced VEGF-induced permeability. Interestingly, they had a therapeutic effect at the lowest dose tested $(10 \mathrm{mg} / \mathrm{kg})$, and that dose was more potent than the higher doses (30 and $100 \mathrm{mg} / \mathrm{kg}$ ). The results obtained are consistent with previous reports, in which the anti-angiogenic therapies were more effective when administered at a more frequent, or metronomic, low-dose schedule [52]. It is postulated that the benzoquinonoid present in QRF might be responsible for the suppression of VEGFinduced permeability. Interestingly, a similar benzoquinonoid compound present in A. crispa was previously reported to possess anti-metastatic activity [24].

In this assay, vascular leakiness of the Evans blue dye was observed at sites of intradermal injection of VEGF, indicating increased vascular permeability. VEGF is a potent permeabilizing mediator that is essential for neovascularisation [53]. Suppression of VEGF reduces vascular leakiness and ultimately prevents the migration of plasma proteins, endothelial cells and fibrin rich matrix that are essential for neovascularisation [54]. Because it was previously reported that $\mathrm{ACRH}$ possesses anti-inflammatory properties by blocking COX-2 [27], the mechanism involved in the attenuation of vascular permeability might involve reduced synthesis of COX-2-derived prostanoids, including PGs. Increased vascular permeability was reported to be elicited by PGs through synergistic effects with other mediators [55]. PGs also contribute to VEGFinduced hyperpermeability by targeting vascular endothelial cells [56]. The mechanism by which $\mathrm{PGE}_{2}$ induces angiogenesis in this study is not fully understood. However, we can speculate that ACRH and QRF can halt neovascularisation by suppressing VEGF-induced vascular permeability.

Murine air pouch granuloma is an animal model of inflammation that is characterised by intense angiogenesis during the chronic inflammatory phase with elevated levels of cytokines, such as interleukin (IL)-1 $\beta$, tumour necrosis factor (TNF) and IL-6, the induction of COX-2, and enhanced $\mathrm{PGE}_{2}$ production [57]. We used this model to assess the regulation of angiogenesis in chronic inflammatory disease. Our results indicate that ACRH and QRF significantly and dose-dependently reduced the VI associated with FCA-induced inflammation, without affecting granuloma size (Tables 2 and 3). The significant suppression of VI elicited by ACRH and QRF indicates there was a significant reduction in the carmine content in blood vessels surrounding the granulomatous tissue. The lowest dose of QRF $(10 \mathrm{mg} / \mathrm{kg})$ reduced angiogenesis to a level similar to that achieved by $10 \mathrm{mg} / \mathrm{kg}$ indomethacin. Therefore, we consider that lower doses of QRF might show better potency once the major bioactive compound has been isolated.

ACRH and QRF blocked angiogenesis without markedly reducing granuloma growth. This differs from the effects of glucocorticoids in this model, which severely inhibit granuloma formation [58]. However, our results are consistent with those reported by Gilroy et al. [59], who used the same model to differentiate between COX-1 and COX-2 inhibitors. This explained the reduction in granuloma weight achieved by indomethacin in our study, consistent with the results of aspirin, a selective COX-1 inhibitor, in a prior study [60]. We found that QRF had a greater anti-angiogenic effect in our study, as the effects of $10 \mathrm{mg} / \mathrm{kg}$ QRF and $100 \mathrm{mg} / \mathrm{kg}$ ACRH were similar. Although the mechanism is not fully understood, we think that ACRH and QRF contain a selective COX-2 inhibitor, considering that our results are consistent with those reported by Gilroy et al. [59].

It is well established that inflammation promotes angiogenesis through several ways. Inflammatory cells such as macrophages, lymphocytes, mast cells and fibroblasts are capable of stimulating vessel growth [60]. Inflammatory mediators, including PGE 1 , PGE 2 , TNF, IL-1, IL-6 and IL8 , in addition to having pro-inflammatory activities, are capable of directly and/or indirectly inducing angiogenesis in vivo, which in turn may stimulate tumourigenesis [61]. 
As inflammation plays a crucial role in inducing rapid angiogenesis in the air pouch model, suppressing inflammation may help to reduce angiogenesis. Our present results may support those of a previous report describing the antiinflammatory activity of Ardisia crispa roots [26]. The primary mode of action of ACRH and QRF might involve anti-inflammatory activities, with their anti-angiogenic potential being secondary. The ability of ACRH and QRF to suppress angiogenesis might be due to their ability to inhibit COX activity. Inflammatory mediators (e.g., PGs) and enzymes (e.g., COX) are involved in rheumatoid arthritis and cancer-induced angiogenesis [3]. Inhibition of COX downregulates the production of inflammatory mediators, and thus reduces the levels of angiogenic mediators [56]. Further studies are needed to confirm the anti-angiogenic activities of ACRH and QRF using a series of models displaying prominent features of angiogenesis, particularly endothelial proliferation, migration and tube formation [62] to further elucidate the mechanisms underlying the antiangiogenic effects of ACRH and QRF.

\section{Conclusions}

The results of this study indicate that ACRH and QRF exert anti-angiogenic effects by suppressing VEGF-induced permeability and reducing inflammation in adjuvant induced air pouch granuloma in mice in vivo. These results confirm the association between angiogenesis and inflammation that was established in previous studies. However, the exact mechanism underlying the anti-angiogenic effects of ACRH and QRF remains to be confirmed. Our current findings provide a scientific basis that will foster further studies in this field.

\section{Competing interests}

The authors declare that they have no competing interest.

\section{Authors' contributions}

DEZAH performed the research and wrote the manuscript. RAH contributed to the experimental design, data interpretation, editing and submission of the manuscript. LSY contributed to the experimental design and data interpretation. CNMT contributed to the experimental design. YLT performed some of the research and data interpretation. All authors read and approved the final manuscript.

\section{Acknowledgements}

The study was funded by the Fundamental Research Grant Scheme (FRGS) from the Ministry of Higher Education, Malaysia (Project no: 02-11-08-616FR). The authors thank the Faculty of Medicine and Health Sciences, Universiti Putra Malaysia for providing the necessary facilities.

\section{Author details}

${ }^{1}$ Department of Biomedical Science, Faculty of Medicine and Health Sciences, Universiti Putra Malaysia, Serdang, Selangor 43400, Malaysia. ${ }^{2}$ Department of Anatomy, Faculty of Medicine and Health Sciences, Universiti Putra Malaysia, Serdang, Selangor 43400, Malaysia. ${ }^{3}$ Department of Paraclinical Science, Faculty of Medicine and Health Sciences, Universiti Malaysia Sarawak, Kuching, Sarawak 93150, Malaysia.

Received: 17 May 2012 Accepted: 4 January 2013

Published: 8 January 2013

\section{References}

1. Woo AYH, Zhao Y, Zhang R, Zhou Z, Cheng CHK: Angiogenesis and Chinese medicinal foods. In Anti-angiogenic functional and medicinal foods. Edited by Losso JN, Shahidi F, Bagchi D. New York: CRC Press; 2007:581-592.

2. Folkman J: Tumor angiogenesis: therapeutic implications. New Engl J Med 1971, 285(21):1182-1186.

3. Folkman J: Angiogenesis in cancer, vascular, rheumatoid and other disease. Nat Med 1995, 1(1):27-31.

4. Khurana R, Simmons M, Martin JF, Zachary IC: Role of angiogenesis in cardiovascular disease: a critical appraisal. Circulation 2005, 112(12):1813-1824

5. Nakano $T$, Nakashima $Y$, Yonemitsu $Y$, Sumiyoshi S, Chen $Y X$, Akishima $Y$, lida $M$, Sueishi K: Angiogenesis and lymphangiogenesis and the expression of lymphangiogenic factors in the atherosclerotic intima of human coronary arteries. Hum Pathol 2005, 36(4):330-340.

6. Chen F, Eriksson P, Kimura T, Herzfeld I, Valen G: Apoptosis and angiogenesis are induced in the unstable atherosclerotic plaque. Coron Artery Dis 2005, 16(3):191-197.

7. Hayden MR, Tyagi SC: Vasa vasorum in plaque angiogenesis, metabolic syndrome, type 2 diabetes mellitus, and atheroscleropathy: a malignant transformation. Cardiovasc Diabetol 2004, 3:1-6.

8. Walsh DA, Pearson Cl: Angiogenesis in the pathogenesis of inflammatory joint and lung diseases. Arthritis Res Ther 2001, 3(3):147-153.

9. Weipeng B, Fei C, Ling B, Ping Z, Wenxin Q: Dihydrotanshinone I inhibits angiogenesis both in vitro and in vivo. Acta Biochim Biophys Sin 2008, 40:1-6.

10. Shishodia S, Sethi G, Aggrawal BB: Curcumin: getting back to the roots. Ann N Y Acad Sci 2005, 1056(1):206-217.

11. Raso GM, Meli R, Di Carlo G, Pacilio M, Di Carlo R: Inhibition of inducible NO synthase and cyclooxygenase- 2 expression by flavonoids in macrophage J774A. Life Sci 2001, 68(8):921-931.

12. Shimamura $M$, Hazato $T$, Ashino $H$, Yamamoto $Y$, Iwasaki $E$, Tobe $H$, Yamamoto K, Yamamoto S: Inhibition of angiogenesis by humulone; a bitter acid from beer hop. Biochem Biophys Res Commun 2001, 289(1):220-224.

13. Kwon HJ, Shim JS, Kim JH, Cho HY, Yum YN, Kim SH, Yu J: Betulinic acid inhibits growth factor-induced angiogenesis via the modulation of mitochondrial function in endothelial cells. Jpn J Cancer Res 2002, 93(4):417-425.

14. Surh YJ: Anti-tumor promoting potential of selected spice ingredients with antioxidative and anti-inflammatory activities: a short review. Food Chem Toxicol 2002, 40(8):1091-1097.

15. Bråkenhielm E, Cao R, Cao Y: Suppression of angiogenesis, tumor growth, and wound healing by resveratrol, a natural compound in red wine and grapes. FASEB J 2001, 15(10):1798-1800.

16. Delmas D, Lançon A, Colin D, Jannin B, Latruffe N: Resveratrol as a chemopreventive agent: a promising molecule for fighting cancer. Curr Drug Targets 2006, 7(4):423-442.

17. Foitzik T, Hotz HG, Hotz B, Wittig F, Buhr HJ: Selective inhibition of cyclooxygenase-2 (COX-2) reduces prostaglandin $\mathrm{E}_{2}$ production and attenuates systemic disease sequelae in experimental pancreatitis. Hepatogastroenterology 2003, 50(52):1159-1162.

18. Hoper MM, Voelkel NF, Bates TQ, Allard JD, Horan M, Shepherd D, Tudier R: Prostaglandin induce VEGF growth factor in human monocytic cell lines and rat lungs via CAMP. Am J Respir Cell Mol Biol 1997, 17(6):748-756.

19. Romano M, Claria J: Cyclooxygenase-2 and 5-lipoxygenase converging function on cell proliferation and angiogenesis: implication for cancer therapy. FASEB J 2003, 17(14):1986-1995.

20. Heyne K: Tumbuhan berguna Indonesia III, translated by Badan Litbang Kehutanan Jakarta. Indonesia: Yayasan Sarana Wana Jaya; 1987.

21. Muhammad Z, Mustafa AM: Traditional Malay Medicinal Plants. Kuala Lumpur: Fajar Bakti; 1994:39-41.

22. Jansakul C, Herbert B, Lennart K, Gunnar S: Ardisiacrispin A and B, two utero-contacting saponins from Ardisia crispa. Planta Medica 1987, 53(5):405-409.

23. Yoshida K, Koma Y, Kikuchi H: Therapeutic substance FR-900359 from Ardisia crispa. Japan Kokkai Tokyo Kobo JP 1987, 283:917-920.

24. Kang YH, Kim WH, Park MK, Han BH: Antimetastatic and antitumor effects of benzoquuinonoid AC7-1 from Ardisia crispa. Int J Cancer 2001, 93(5):736-740.

25. Roslida $\mathrm{AH}$, Teh $\mathrm{YH}$, Kim KH: Evaluation of anti-ulcer activity of Ardisia crispa Thunb. D.C. PharmacognRes 2009, 1:250-255. 
26. Roslida AH, Kim KH: Anti-inflammatory effect and anti-hyperalgesic effect of Ardisia crispa Thunb D C. Pharmacogn Mag 2008, 4:262-268.

27. Roslida AH: Anti-inflammatory and analgesic effects of $A C-2$ isolated from Ardisia crispa are mediated via COX-2 inhibition. Kuala Lumpur, Malaysia: PhD thesis, Universiti Malaya, Physiology Department; 2004.

28. Jackson JR, Seed MP, Kircher CH, Willoughby DA, Winkler JD: The codependence of angiogenesis and chronic inflammation. FASEB J 1997 11(6):457-465

29. Wang W, Bergh A, Damber JE: Cyclooxygenase-2 expression correlates with local chronic inflammation and tumor neovascularization in human prostate cancer. Clin Cancer Res 2005, 11(9):3250-3256.

30. Ghosh AK, Hirasawa N, Niki H, Ohuchi K: Cyclooxygenase-2 mediated angiogenesis in carageenin- induced granulation tissue in rats. $J$ Pharmacol Exp Ther 2000, 295(2):802-809.

31. Form DM, Auerbach R: $\mathrm{PGE}_{2}$ and angiogenesis. Proc Soc Exp Biol Med 1983, 172(2):214-218.

32. Stjernschantz J, Nilsson SFE, Astin M: Vasodynamic effects of eicosanoids in the eye. Prog Clin Biol Res 1989, 312:155-170.

33. Cohen T, Nahari D, Cerem LW, Neufeld G, Levi BZ: Interleukin-6 induces the expression of vascular endothelial growth-factor. J Biol Chem 1996, 271(2):736-741.

34. Ben-Av P, Crofford LJ, Wilder RL, Hla T: Induction of vascular endothelial growth factor expression in synovial fibroblasts by prostaglandin $\mathrm{E}$ and interleukin-1: a potential mechanism for inflammatory angiogenesis. FEBS Lett 1995, 372(1):82-87.

35. Folkman J, Brem H: Angiogenesis and inflammation. In Inflammation: basic principles and clinical correlates. 2nd edition. Edited by Gallin JI, Goldstein IM, Snyderman R. New York: Raven; 1992:821-839.

36. Ayoola GA, Coker HAB, Adesegun SA, Adepoju-Bello AA, Obaweya K, Ezannia EC, Atangbayila TO: Phytochemical screening and antioxidant activites of some selected medicinal plants used for malaria therapy in southwestern Nigeria. Trop J Pharm Res 2008, 7(3):1019-1024.

37. Shelar R, Maurya C, Tekale P, Katkar K, Naik V, Suthar A, Chauhan VS: Embelin - An HPLC Method for Quantitative Estimation in Embelia ribes Burm. F: Int J Pharm Clin Res 2009, 1(3):146-149.

38. Veerappan A, Miyazaki S, Kadarkaraisamy M, Ranganathan D: Acute and subacute toxicity studies of Aegle marmelos Corr., an Indian medicinal plant. Phytomedicine 2007, 14(2-3):209-215.

39. Pakhneshan P, Birsner AE, Adini I, Becker CM, D'Amato R: Differential suppression of vascular permeability and corneal angiogenesis by nonsteroidal anti-inflammatory drugs. Invest Ophthalmol Vis Sci 2008, 49(9):3909-3913.

40. Wang C, Duan $H$, He L: Inhibitory effect of atractylenoline I on angiogenesis in chronic inflammation in vivo and in vitro. Eur $J$ Pharmacol 2009, 612(1-3):143-152.

41. Jackson JR, Bolognese B, Hillegass L, Kassis S, Adams J, Griswold DE, Winkler JD: Pharmacologcal effects of SB 220025, a selective inhibitor of P38 mitogen-activated protein kinasem in angiogenesis and chronic inflammatory disease models. J Pharmacol Exp Ther 1998, 284(2):687-692.

42. Gonzalez de Mejia E, Ramirez-Mares MV: Ardisia: health-promoting properties and toxicity of phytochemicals and extracts. Toxicol Mech Methods 2011, 21(9):667-674.

43. Fukuyama Y, Kiriyama Y, Okino J, Kodama M, Iwaki H, Hosozawa S: Naturally occurring 5-lipoxygenase inhibitor. II. Structures and syntheses of ardisianones $A$ and $B$, and maesanin, alkenyl-1, 4-benzoquinones from the rhizome of Ardisia japonica. Chem Pharm Bull 1993, 41(3):561-565.

44. Fukuyama Y, Kiriyama Y, Okino J, Kodama M, Iwaki H, Hosozawa S: Total synthesis of ardisiaquinone $\mathrm{A}$, a potent 5-lipoxygenase inhibitor, isolated from Ardisia sieboldii, and degree of 5-lipoxygenase inhibitory activity of its derivatives. Chem Pharm Bull 1994, 42(10):2211-2213.

45. Chang HS, Lin YJ, Lee SJ, Yang CW, Lin WY, Tsai IL, Chen IS: Cytotoxic alkyl benzoquinones and alkyl phenols from Ardisia virens. Phytochemistry 2009, 70(17-18):2064-2071.

46. Ong CY, Ling SK, Ali RM, Chee CF, Samah ZA, Ho AS, Teo SH, Lee HB: Systematic analysis of in vitro photo-cytotoxic activity to extracts from terrestrial plants in Peninsula Malaysia for photodynamic therapy. J Photochem Photobiol 2009, 96(3):216-222.

47. Knighton D, Asprunk D, Tapper D: Avascular and vascular phase of tumor growth in the chick embryo. Br J Cancer 1977, 35(3):347-356.
48. Gimbrone MA Jr, Cotran RS, Leapman SB, Folkman J: Tumor growth and neovascularization, an experimental model using rabbit cornea. J Natl Cancer Inst 1974, 52(2):413-427.

49. Zhang J, Sun Y, Zhang JQ, Ramires FJ, Weber KT: Appearance and regression of rat air pouch tissue. J Mol Cell Cardiol 1999, 31(5):1005-1013.

50. Verheul HM, Panigrahy D, Yuan J, D'Amato RJ: Combination oral antiangiogenic therapy with thalidomide and sulindac inhibits tumour growth in rabbits. Br J Cancer 1999, 79(1):114-118.

51. Senger DR, Van deWater L, Brown LF, Nagy JA, Yeo KT, Yeo TK, Berse B, Jackman RW, Dvorak AM, Dvorak HF: Vascular permeability factor (VPF/VEGF) in tumor biology. Cancer Metastasis Rev 1993, 12(3-4):303-324.

52. Jennifer $A D$, Jennifer $E H$, Gerald $E H$ : Role of apoptosis in anti-angiogenic cancer therapies. In Apoptosis, Senescence and Cancer. Edited by Gewirtz DA, Holt SE, Grant S. New Jersey: Humana Press Inc; 2007:537-556.

53. Chiarugi V, Magnelli L, Gallo O: COX-2, iNOS and p53 as play-makers of tumor angiogenesis. Int J Mol Med 1998, 2(6):715-719.

54. Vasile E, Qu-Hong, Dvorak HF, Dvorak AM: Caveolae and vesiculo-vacuolar organelles in bovine capillary endothelial cell cultured with VPF/VEGF on floating matrigel-collagen gel. J Histochem Cytochem 1999, 47(2):159-167.

55. Funk CD: Prostaglandins and leukotrienes: Advances in eicosanoids biology. Science 2001, 294(5548):1871-1875.

56. Murohara T, Horowitz JR, Silver M, Tsurumi Y, Chen D, Sullivan A, Isner JM: Vascular endothelial growth factor/vascular permeability factor enhances vascular permeability via nitric oxide and prostacyclin. Circulation 1998, 97(1):99-107.

57. Leahy KM, Koki AT, Masferrer JL: Role of Cyclooxygenases in Angiogenesis. Curr Med Chem 2000, 7(11):1163-1170.

58. Colville-Nash PR, Alam CA, Appleton I, Browne JR, Seed MP, Willoughby DA: The pharmacological modulation of angiogenesis in chronic granulomatous inflammation. J Pharmacol Exp Ther 1995, 274(3):1463-1472.

59. Gilroy DW, Tomlinson A, Willoughby DA: Differential effects of inhibition of isoforms of cyclooxygenase (COX-1, COX-2) in chronic inflammation. Inflamm Res 1998, 47(2):79-85.

60. Qu Z, Huang XN, Ahmadi P, Andresevic J, Planck SR, Hart CE, Rosenbaum JT: Expression of basic fibroblast growth factor in synovial tissue from patients with rheumatoid arthritis and degenerative joint disease. Lab Invest 1995, 73(3):339-346.

61. Remmers EF, Sano H, Wilder RL: Platelet-derived growth factors and heparin binding (fibroblast) growth factors in the synovial tissue pathology of rheumatoid arthritis. Semin Arthritis Rheum 1991, 21(3):191-199.

62. Hua $H$, Feng $L$, Zhang $X P$, Zhang $L F$, Jin J: Anti-angiogenic activity of julibroside $J_{8}$, a natural product isolated from Albizia julibrissin. Phytomedicine 1999, 16(8):703-711.

doi:10.1186/1472-6882-13-5

Cite this article as: Hamsin et al:: The hexane fraction of Ardisia crispa Thunb. A. DC. roots inhibits inflammation-induced angiogenesis. BMC Complementary and Alternative Medicine 2013 13:5.

\section{Submit your next manuscript to BioMed Central and take full advantage of:}

- Convenient online submission

- Thorough peer review

- No space constraints or color figure charges

- Immediate publication on acceptance

- Inclusion in PubMed, CAS, Scopus and Google Scholar

- Research which is freely available for redistribution 